\title{
EFFICIENCY OF LEGAL SOLUTIONS IN FIGHT AGAINST DOMESTIC VIOLENCE
}

Domestic violence has had a long tradition, both in Serbia and countries of the region. Owing to deep rooted patriarchal traditions, for centuries this socially pathological phenomenon has had many supporters and for a long time it was considered socially acceptable. Laws and bylaws adopted in the past decade have significantly improved the legal framework in protection of domestic violence victims. However, inefficiency of their application in practice, caused by slow and long resolution processes, and the issues of the very acts of domestic violence and custody, have led to an escalation in domestic violence. This is greatly enabled by the fact that false reports while the acts occur go unpunished, which makes it possible for real abusers to use this tactic and prolong the stress situation for the real victim, in some cases, for years.

The aim of the authors is to do a comparative analysis of laws in the region and consequences of their application, therefore defining problems that present obstacles for adopted laws and suggest new solutions.

Key words: domestic violence, false reports, custody, court proceedings

\section{INTRODUCTION}

A socially pathological phenomenon, domestic violence has been long present in the history of humanity. At one point in time it was considered socially acceptable and even encouraged as a type of "corrective measure". As the society developed, so did the social standards of (un)acceptable behaviour, but for this particular phenomenon, the world has needed many centuries to pass to realize it is a practice that will not become a relic of the past that easily. If nothing else, we get the impression that the amount of domestic violence occurring each year has only been increasing, although the story of human rights began a

\footnotetext{
* Mina Zirojević, PhD, Research Fellow, Institute of Comparative Law, Belgrade. Email: m.zirojevic@iup.rs.

** Darija Marković, LL.B (Hons), Master student at RUDN University, Moscow, orcid.org/0000-0001-5602902X. Email: darija.dm.markovic@gmail.com.
} 
long time ago. On the other hand, it could simply be a case of a bigger amount of courage on the victims' part to report their abusers.

Overall, the number of domestic violence reports in Serbia is alarming, and the dark figure of crime in relation to domestic violence is presumed to be high, since this phenomenon affects all aspects of a person's life. In the 27 months since the Law on Prevention of Domestic Violence entered into force in Serbia was adopted, almost 110.000 cases were reported (Bogosav, 2019). Taking into consideration Serbia's population, this is a fairly high number of cases. According to the Ministry of Justice of Serbia, 12.332 victims of domestic violence have been registered by August 2020, and although the COVID-19 pandemic could potentially put more persons at risk, the NGOs claim that there have been no abnormalities in the number of reports during the state of emergency (Al Jazeera Balkans, 2020). Nevertheless, the ongoing pandemic still presents an aggravating factor for victims of domestic violence, not only in Serbia, but everywhere. The countries of the Western Balkans region are often seen as one entity mainly because of similar traditions and mentality, a common past and legal framework that they have shared before. In terms of family relations, a tradition that is strictly patriarchal is the basis of legal acts. Adding the COVID-19 pandemic into the equation, setbacks in the progress made, with already existing problems in battle against domestic violence, seem to be imminent. Therefore, the authors take a look at legal frameworks in some of the countries of the region, then go on to observe the problems in practice, all with a specific focus on the issues of false reports, duration of court proceedings, protective measures, penal policy, and child custody and visitation rights. The aim of the authors is to identify problems for adopted laws and suggest new solutions.

\section{DOMESTIC VIOLENCE IN SERBIA}

Domestic violence was first introduced as a separate crime in the Criminal Code of Serbia in 2002. It marked the beginning of the legal reform pertaining not only to domestic violence, but also gender based violence. The Family Code from 2005 also defined domestic violence and prescribed protective measures that can be issued by civil courts. Another relevant law would be the Law on Gender Equality from 2009, which also prohibited domestic violence. The Law on Prohibition of Discrimination was adopted the same year, and it, too, proscribes certain acts of violence and defines procedures to be taken by civil courts. In 2013 Serbia ratified the Istanbul Convention, taking on the task of improving and harmonizing its legislation in relation to domestic violence, discrimination and violence against women.

Since then, the normative framework has been upgraded several times pertaining to both domestic violence and acts related to it, as well as actions that should be taken by relevant institutions in these cases. A large step in that direction were amendments to the Criminal Code and the adoption of the Law on Prevention of Domestic Violence in 2016. What distinguishes Serbian Law on Prevention of Domestic Violence from those in the region, which were previously mentioned in this paper, is the fact that it supports the Criminal Code and Family Law. That means that domestic violence is primarily 
considered a felony in Serbia, while violations of some protective measures could be considered misdemeanours. From the preventive perspective, defining domestic violence only as a felony leaves a clear message, which is that minimum, if any, tolerance should be shown to such acts. However, according to the Law on Public Order and Peace certain forms of physical and psychological violence could be prosecuted as misdemeanours, and consequently, according to the Law on Misdemeanours, several protection measures can be issued by misdemeanour courts.

In addition to the amendments and new laws, Serbia also adopted several procedural guidelines, which are intended to help police, prosecution, courts, social services and health institutions.

\subsection{Problems in practice}

Although Serbian laws have not been long in effect, they are to a great degree in harmony with international treaties and requirements posed by the EU. Nevertheless, many problems arise in practice for the lack of proper interpretation, education and training and logistical support.

A new trend that has been on the rise since the Law on Prevention of Domestic Violence entered into force in 2017 are false reports. False reports represent a clear abuse of basic human rights, taking into consideration all the possible consequences they could entail. According to one prosecutor's office in Belgrade (Prvo Osnovno Javno Tužilaštvo $\mathrm{u}$ Beogradu, 2018), in the year following the adoption of the Law on Prevention of Domestic violence they had more than 600 reports of domestic violence, among which false reports occurred a number of times. This is why they said it is important to carefully examine all facts, although they admitted that is much easier in cases of physical violence because medical experts can verify the claims. If the prosecution unveils false reporting, they ex officio indict the person in question for false reporting. However, false reports do not only hinder the prosecution but courts, as well. Judges agree with prosecutors that false reports occur because individuals wish to exploit the system, mostly during divorce proceedings, for personal vendetta, achieving advantage in custody battles and similar (The Advocates for Human Rights \& the Autonomous Women's Center, 2017). False reports could result in the falsely accused person being evicted from their home, which is why judges state that they should act with particular caution when considering this protective measure. One judge even stated that approximately $30 \%$ of eviction requests are based on false reports (The Advocates for Human Rights \& the Autonomous Women's Center, 2017, p. 31). With such a high percentage of false reports, it is no wonder that judges show reluctance to issue protective measure, especially eviction, which is one of the most important ones. A worrisome practice, also noted by the judges (The Advocates for Human Rights \& the Autonomous Women's Center, 2017, p. 87), is that lawyers suggest their clients submit false reports so as to speed up the proceedings in their favour. Under normal circumstances, lawyers recommending/suggesting committing illegal acts, should be at least held disciplinary responsible, however, realistically, this is difficult to prove in courts where principle of material truth prevails. 
False reports are not the only problem in court proceedings. In Serbia, family, criminal and misdemeanour courts decide in domestic violence cases. There are numerous problems in each of these instances, but here we will go through several common denominators. When it comes to duration of court proceedings, misdemeanour proceedings are the fastest, while criminal proceedings take the longest time. Nevertheless, in all types of proceedings delays occur for several reasons. The courts are understaffed with heavy caseloads. A significant decrease in misdemeanour case, but an increase in criminal cases since 2016 just shows that cases moved to these courts. In judges' opinion, about $1 / 3$ of all criminal cases are domestic violence cases, which is truly a lot. Additionally, they claim that delays mostly occur because of summons. Since summons need to be personally received, they are often subject to manipulation. The accused are prone to changing home addresses or similar actions in order to evade appearing in court, while courts wait too long to use all other measures to ensure expedience of proceedings. (The Advocates for Human Rights \& the Autonomous Women's Center, 2017)

Another issue is the lack of protective measures issued by all courts and the lack of monitoring if they are respected, which is the same problem as in the region. In Serbia, too, the courts tend to be lenient with sentences with an extremely low percentage of protective measures issued. More than half of the sanctions are suspended sentences, a trend that does not seem to waning, and although almost $40 \%$ of punishments constitute prison sentences, protective measures were issued in only $2-4 \%$ of cases, usually together with suspended or prison sentence (Petrušić et al., 2018, pp. 60-61). Lenient penal policy and an extremely limited amount of protective measures issued do not serve neither the preventive nor repressive purpose. Such practice only leaves more space for recidivism and, more importantly, it discourages victims from reporting domestic violence, since it seems the relevant institutions cannot provide adequate protection.

It is obvious that violence is not taken seriously enough, risk assessment is unsatisfactory, and judges are not trained well enough, particularly in cases involving psychological violence. They rely too much on reports submitted by social services, which are not binding, and aim to preserve "family". Such practice leaves the impression that the definition of family end on a purely biological note, without taking into consideration basic human rights all family members have individually. For example, since alcohol is a factor in majority of domestic violence cases, they usually tend to go for conciliation and, possibly, treatment for the perpetrator, regardless of the fact that this could prolong both physical and psychological violence, or secondary violence if children are witnesses to the violence. Lack of understanding for the victims is reflected in the practice of confrontation in family and misdemeanour courts, where courtrooms are small and without proper security. Such conditions further aggravate the stress situation of having gathered courage to report domestic violence and expose oneself to the entirety of administrative processes in order to get protection. To our findings, criminal courts do not practice confrontation, however, if the victim does not testify, they simply close the case, even though Serbian courts should decide based on the principle of material truth and could proceed with the trial ex officio. (The Advocates for Human Rights \& Autonomous Women's Center, 2017) 
In connection to the aforementioned practice of Serbian courts, namely their aim to preserve family, it appears that the basic human rights standard "in the best interest of the child" is not quite properly interpreted. The courts, and other institutions, show unsatisfactory level of ability to assess risk to the child, whether they are victims to primary or secondary abuse, or take children's opinion into consideration. In general, courts are of opinion that a child should have contact with both parents, even when that child may have witnessed violence or personally experienced it. In more than half of the cases, the courts decided that children should have "free" (31\%) or "standard" (32\%) visitation arrangements with abusive fathers (Ignjatović \& Macanović, 2018, p. 58). Even when protective measures were issued, perpetrators found ways to evade those measures, without consequences, all because execution of protection orders is not being monitored (The Advocates for Human Rights \& Autonomous Women's Center, 2017, p. 40). If the perpetrators continued committing violent acts despite protective measures, they suffered no consequences. In one case, a father retained the right to visit his children even after kidnapping his stepchild and threatening both the victim and the social worker (The Advocates for Human Rights \& Autonomous Women's Center, 2017, p. 115).

Furthermore, there is no real communication in and between courts. Misdemeanour courts do not take into consideration if the accused has a criminal record, particularly in summary proceedings, while within family courts two parallel cases with same parties could conclude in clashing decisions. For example, in one case, a judge issued protective measures in domestic violence case, prohibiting the perpetrator from visiting his spouse and children, while in the other case pertaining to their divorce and child custody, another judge granted the perpetrator the right to visit his children (The Advocates for Human Rights \& Autonomous Women's Center, 2017, p. 42). What further aggravates custody battles in cases of domestic violence are private prosecutions (The Advocates for Human Rights \& Autonomous Women's Center, 2017, pp. 51-52). Perpetrators sue victims for violence, which results in children usually being taken by the social services and put into foster care.

In Serbia courts significantly rely on reports and recommendations of the Centre for Social Work, which even in cases where the mother was victim to domestic violence, recommend children be put into foster care, either for economic reasons or because she is seen as unable to care for her children properly, seeing as how she could not protect children from violence. On this matter, the authors agree with GREVIO $(2020$, p. 42) that the practice of removing children from the non-abusive parent's care should be brought to an end, since it can cause additional trauma and the foster care system does not offer a proper support system. In relation to that, relevant institutions should be more pensive when deciding on the non-abusive parent's, i.e. the victim's ability to care for their children.

\section{DOMESTIC VIOLENCE IN THE REGION}

Mentions of "domestic violence" appeared only in more recent history of these countries. It can be noticed that the process of implementing this phrase into national legislations has taken time in the countries of the region and has only taken more swing with bigger pressure from the European Union (EU). Although countries of the region are signatories to 
international conventions calling upon member states to provide further national support in battle against domestic violence, countries of the region have become more active in this area only about 15 years ago. Overall, countries of the regions all became more proactive after signing the Council of Europe Convention on Preventing and Combating Violence Against Women and Domestic Violence, also known as the Istanbul Convention (CETS, 2011).

However, even with newly adopted laws on domestic violence and taking on different projects tackling this issue, problems still arise in practice and the overall statistics and results cannot be considered completely successful.

\subsection{Bosnia and Herzegovina}

This is a country with a complex organization of the state. It is constituted of two entities, Federation of Bosnia and Herzegovina and Republika Srpska, and one administrative unit of local self-government, District Brčko of Bosnia and Herzegovina. Each of these units has its own legislation applicable on their respective territories, in addition to legal acts adopted at the state level. With the adoption of the Law on Gender Equality of Bosnia and Herzegovina in 2003 the reform of the legal system began, in relation to sanctioning domestic violence. However, on the level of entities, legal reforms took individual routes.

In 2003 Federation of Bosnia and Herzegovina introduced domestic violence as a crime in Article 222 of its Criminal Code, however in Republika Srpska and District Brčko domestic violence remained at the level of offense. The Federation of Bosnia and Herzegovina went even further by adopting the Law on Protection from Domestic Violence in 2005, becoming the first entity to do so. To this day, individual laws have been amended or changed completely, but what is significant is the fact that both entities and District Brčko adopted Laws on Protection from Domestic Violence. The mentioned laws are more or less in accordance with each other, they all define domestic violence in a more detailed manner as compared to the general definition of domestic violence that can be found in international conventions, such as the Istanbul Convention. The adoption of these laws has been significant for the victims, as it was designed to provide them with protection while waiting for the criminal proceedings to come to an end. Since these proceedings often span over a lengthy period, it was a smart step on the legislators' side. Domestic violence has also been sanctioned as felony in Criminal Codes of all entities of Bosnia and Herzegovina, with latest amendments introducing harsher punishments. However, the Laws on Protection from Domestic Violence of Republika Srpska and District Brčko prescribe which acts of domestic violence are considered misdemeanours, and therefore punishable, when there are no elements of felony. Still, this could become a reason for confusion and improper application in practice. It is also interesting to mention that the Family Law of Republika Srpska does not include or prohibit domestic violence, but Family Laws of Federation of Bosnia and Herzegovina and District Brčko do.

Besides these, on a both local and state level, several strategies and action plans were adopted on the topic of domestic and gender based violence, which further reinforced the legislation in their intention to combat domestic violence. 
Overall, we can agree with Mušić (2018, p.187) that the legal framework regulating domestic violence in Bosnia and Herzegovina has been harmonized with the already established international standards and requirements posed by the international community to a great extent, but it still needs more harmonization internally because, as we have already stated, the state organization of Bosnia and Herzegovina is complex to say the least.

\subsubsection{Efficiency in practice}

The opinion of international organizations (OSCE, 2019), NGOs (Petrić et al., 2019) and other relevant stakeholders (Udruženje žena sudija u Bosni i Hercegovini, 2012) is unified when it comes to Bosnia and Herzegovina. Although theoretically, legally to be more precise, good foundations have been set, application of these norms in practice still poses a problem.

Searching for information on false reports of domestic violence in Bosnia and Herzegovina, we were surprised not to have been able to find any. However, it seems that a greater issue lies beneath. The bigger problem are not maluses of definition of domestic violence, but rather the lack of reporting it. Even with the good normative basis, the percentage of domestic violence keeps rising, especially under the latest circumstances, which is the COVID-19 pandemic. Only during the pandemic, by May 2020, there was a $20 \%$ increase in domestic violence, according to the NGOs reports (Erjavec, 2020). Most often the violence is not reported because victims believe it to be a "private matter" and they wanted to deal with the problems themselves or with the help of a friend (OSCE, 2019), which is certainly conditioned to a degree by the lack of confidence in the police (Muftić \& Cruze, 2014) and other institutions (Mušić, 2018, p. 186).

Another practical issue are the court proceedings. The complex legal system of Bosnia and Herzegovina does not make it easy for the police or the courts to initiate court proceedings on accounts for domestic violence. This problem has been the topic of many reports, academic papers, guidelines and recommendations. One of the main issues is the fact that domestic violence is often qualified as misdemeanour and not felony, which means that perpetrators are not punished as severely (OSCE, 2019, p. 74). This problem is present precisely because the laws treat domestic violence as both a misdemeanour and a felony, depending on the circumstances. However, this creates confusion within the relevant institutions, which tend to view such actions with more leniency.

Without delving further into the topic of penal policy, it is important to emphasize that protective measures are not being issued sufficiently enough. Although Laws on Protection from Domestic Violence in all entities proscribe protective measures that can be issued, the courts tend to avoid this practice. Lamentably, this bad practice has not seen much change since the adoption of relevant laws, although it was acknowledged that it should be done particularly because criminal proceedings take a long time to complete (Udruženje žena sudija u Bosni i Hercegovini, 2012, pp. 13-16). Both academia (Tulumović, 2018, p.71) and practice (Galić \& Huhtanen, eds., 2014) agree that the courts are more concerned with the repressive measures than providing protection to the victims in real time. Nevertheless, protective measures should be issued to provide victims with necessary support and, 
needless to say, protection from stressful situations. This is especially important at present time, with the ongoing COVID-19 pandemic, when many victims have been denied proper protection from perpetrators.

In close relation to the issue of court proceedings, is the question of custody and visitation rights. A statement from an interviewed female (OSCE, 2019, p. 60) is an example of this problem: "I was in an intense conflict with the same employee of the social welfare centre. It lasted for the entire year and a half of the divorce proceedings. I can't believe that she disparaged me because I'm blind and asked me to give up my children because I don't have money." We can notice two problems here. The first one is the duration of the divorce proceedings, and although we do not know, it is possible that protective measures were not issued in this case, which means that the victim was possibly exposed to protracted violence. Secondly, the victim's treatment by the social services is anything but non-discriminatory. According to the Alternative Report of Nongovernmental Organizations from the Bosnia and Herzegovina to GREVIO Group (Petrić et al., 2019, p. 95) in Republika Srpska officials are not properly implementing the Law on Protection from Domestic Violence by insisting on the right of the child to contact with the other parent, even in cases when the other parent was the abuser or the child was refusing to visit with them. What is more, abusive parents are encouraged to keep in contact with their children, disregarding the right of the child to be safe. Here we can see the consistency in bad practice: limited issue of protective measures and obvious disregard for victims' safety. In the mentioned Report (Petrić et al., 2019, p. 97) no available data could be found for the Federation of Bosnia and Herzegovina on the topic of custody/visitation rights, which can only lead us to the conclusion that there is not an efficient data collection system in action, but that is not the topic of this paper. Nevertheless, an example (Petrić et al., 2019, p. 98) was given stating that there have been several cases where violence continued to happen during divorce proceedings or even after them. In those cases, the father (perpetrator) kept the children with him and did not allow contact with children's mother (victim) although there were final court decisions granting custody to the mother. According to the same source, institutions are powerless in these cases, which consequentially gravely violates basic human rights.

\subsection{Montenegro}

The year 2003 was symbolic for Montenegro as well, which was at the time part of the state union Serbia and Montenegro. It was the year domestic violence was introduced into the Criminal Code of Montenegro as a felony. The formulation of the felony is almost the same, if not the same as in Bosnia and Herzegovina, or rather, it is in accordance with international recommendations. However, unlike Bosnia and Herzegovina, Montenegro adopted the Law on Protection from Domestic Violence only ten years ago, but unlike them they firstly defined domestic violence in the most general way, while the stipulations regarding the misdemeanour acts considered to be domestic violence are defined in the third part of the Law. The Law also defines protective measures that can be issued in cases of domestic violence. Following the adoption of the Law on Protection from Domestic Violence, Montenegro adopted a strategy that would serve as a project to create the 
Protocol on Actions, Prevention of and Protection from Domestic Violence (Procedures and institutional cooperation regarding domestic violence and violence against women), which was signed in November 2011. However, as the IPSOS research stated (2017, p. 108) the Protocol is not binding, so although it offers guidelines on the interinstitutional cooperation, those solutions remain mere recommendations. Another lex specialis worth mentioning is the Law on Gender Equality, initially adopted in 2007 with latest amendments in 2015, since it includes domestic violence as one of the acts of gender based violence.

Action plans and strategies were created immediately following the adoption of the Law on Gender Equality and Law on Protection from Domestic Violence respectively. These have helped Montenegro stay on the good track of harmonizing its legal framework with standards imposed by the Istanbul Convention and the EU recommendations in battle against domestic violence.

All in all, it is obvious that in the past decade Montenegro has been proactive on the topic of domestic violence. The progress made in the normative aspect has been significant, yet there are still issues in practice, both due to the fact that the Protocol on Action, Prevention of and Protection from Domestic Violence is only recognized as a guideline and not an obligatory document, and that norms are not being interpreted properly (Ministarstvo pravde, 2016).

\subsubsection{Efficiency in practice}

Results of the IPSOS Strategic Marketing research within the program "Support to antidiscrimination and gender equality policies" (2017, p. 63) showed that the police had experience with false reports of domestic violence, mostly during divorce proceedings. The police officers' positions on reporting all types of violence differ. While some police officers believe all types of violence should be reported and investigated properly, other view reporting "one offensive SMS" or similar forms of psychological violence without proof should not be taken into consideration because it takes away the time they could spend investigating other, more serious cases. Nevertheless, the police stated that they act upon all reports of domestic violence, which can be considered good practice. A 2018 case before ombudsman (broj 223/18) is in line with the claim from the IPSOS research. Namely, the ombudsman received a complaint concerning abuse of the Law on Protection from Domestic Violence. In this case a woman reported her former husband for supposed violence based on gender. ${ }^{310}$ Several things can be noted from this case. First of all, the Ombudsman investigated this case efficiently, coordinating with the police and the social services. Secondly, many factors were taken into consideration in this case and all relevant legislation was consulted, as should be done in cases of possible domestic violence. Finally, it was established that this might have a been a case of false reporting, which is punishable according to the Criminal Code of Montenegro, but the Ombudsman did not give his qualification since it is not his jurisdiction and neither was it truly possible to prove it.

${ }^{310}$ For more information read opinion of Ombudsman of Montenegro at: https://www.ombudsman.co.me/ docs/1528721329_05062018-preporuka-csr.pdf. 
Indeed, in borderline cases, it is usually difficult to prove that there was false reporting, but even if there have been cases where false reports were obviously such, we could not find any information on those acts being prosecuted.

The area where normative frameworks are put onto test are court proceedings. The courts are generally overloaded with work and do not have enough staff to efficiently resolve cases. It is not any different in Montenegro. In the courts' opinion (IPSOS, 2017, p.88) domestic violence cases are being solved quickly enough, though it may seem to the broader public that the proceedings last long and end in mild punishments. According to them, the public may have gotten that impression because each of these cases ought to be approached with maximum attention to detail. However, one of the problematic details in these cases is the principle of urgency of procedure. According to the Criminal Code no urgent action is required in domestic violence cases (Zeković et al., eds., 2017, p. 129), all the while it is not possible for protection measures to be issued until the final decision is made (GREVIO, 2018, p. 55). Although misdemeanour proceedings go much faster and protection measures can be issued before, during and after the proceedings, the practice shows that courts are lenient in their deciding. There is a high percentage of acquittals, fines and other alternative punishments without protective measures being issued, even though the law allows it (Zeković et al., eds., 2017, p. 129). It is obvious that here, as well, more stress is put on the repressive aspect of domestic violence cases, if we can even call it that, having in mind the previously stated, while the victims remain unprotected and obviously discouraged from future reporting. This is further supported by the fact that, although insufficiently, protective measure of removal from the residence and other premises for housing has been issued by the police, it is often not prolonged by the courts (IPSOS, 2017, p. 65) and that even when it has been issued, it cannot have the same effect without other protective measures being imposed with it (J.B.Č., 2019).

Finally, the issue of child custody in domestic violence cases in Montenegro shows that the institutions are still lacking proper procedures and more consideration for the victims. A study from 2012 (CEED, 2012, p. 16) defined a series of recommendations pertaining to children's safety in cases of domestic violence, stating that courts should be enabled to grant temporary custody to the nonviolent parent during proceedings. Among other things, the study recommends allowing visitation rights to the abusive parent in a manner that would provide maximum security for the child, particularly in cases where there is a possibility of abduction. Therefore, supervised visitations are possible, as long as they are in the best interest of the child. However, the GREVIO report $(2018$, p. 41) showed that in practice not enough attention was given to how witnessing violence or being the victim can affect the children's minds, and to what degree it can pose a danger to them. In addition to that, they noted that although the mechanisms exist, in majority of cases the courts did not opt for supervised visitations. On several occasions, even though they were supervised visitations, children were abducted by their fathers. To top it all off, the same report points out discrimination towards female victims/mothers, which reflects in the work of social services that give advantage to the "classic idea" of family with a male as its head. The case study from 2017 (Zeković et al., eds., 2017, p. 99-101) included a case in which daughters were returned to their abusive father, who was eventually sentenced to 6 
months in prison/2 years of parole, whereby the social services were obliged to work on building family relationship between father and daughters. In another case study (Zeković et al., eds., 2017, p. 105-106) the children were left in the custody of their father who abused their mother. Due to the circumstances of the abuse, the mother lost her employment and housing, which is why the children were entrusted with their father, who denied their mother granted visitation rights. This case is an example of children witnessing violence of one parent against the other, which could mentally affect them negatively and affect their future lives.

Nevertheless, there have been examples of good practice, but they are outshined by the number of badly led court proceedings and interpretations of the basic human rights standards, and disregard for the risks to the victims. It remains to be seen what results the Strategy on Protection from Domestic Violence 2016-2020 will show at the end of this year.

\subsection{Croatia}

A recent addition to the EU, Croatia has battled the issue of domestic violence for almost two decades. With the adoption of Law on Protection from Domestic Violence in 2003 Croatia showed its will to deal with both domestic violence and violence based on gender. The Law on Protection from Domestic Violence has gone through changes over the years, and a new version entered into force at the very begging of this year. As is the case with its neighbours, Bosnia and Herzegovina and Montenegro, the Law on Protection from Domestic Violence defines domestic violence, sanctions domestic violence as misdemeanour and prescribes protective measures that can be issued even before the beginning of misdemeanour proceedings. Together with the Law, several rulebooks were adopted, as well. These rulebooks serve as guides in implementation of specified articles. In 2005 adopted its first Protocol on the Procedure in Cases of Domestic Violence and has been adopting new Protocols as the laws were amended. The last Protocol was adopted in 2019 and its role is to indicate how interinstitutional approach should be implemented in practice. Domestic violence is also defined as a crime in the Criminal Code of Croatia, although in a narrower sense than in the Law on Protection from Domestic Violence. Since the adoption of the first Law on Protection from Domestic Violence, Croatia has also been developing strategies in this area.

However, in 2018 a controversy arose in the Croatian society. In 2018 Croatia ratified the Istanbul Convention, but this addition to their legislation did not receive a warm welcome. Obviously, there might have been some reservations about the Convention, seeing as how it was ratified five years after they signed it, but its ratification caused massive protests supported by clerical and conservative right-winged circles (Bodiroga-Vukobrat, 2018) request a referendum on the topic of the Istanbul convention. Nevertheless, Croatian legislation needs to put more effort into harmonization now that the Istanbul Convention has been ratified. 


\subsubsection{Problems with efficiency in practice}

Croatia, too, has been facing an increasing number of false reports. However, lack of reports and statistics in the past 10 years has made victims of false reports turn to media. That is how we, too, have been able to find out about cases of false reports in Croatia (Raić Knežević, 2020). Male victims of false reports enter a system of discrimination based on the automatic supposition that they are abusers. True to the fact, majority of perpetrators are males, yet it does not justify improper work of relevant institutions. False reports, especially if repeated, can be treated as a type of psychological and physical violence, but more often than not they go unpunished.

The Law on Protection against Domestic Violence prescribes that in all cases related to domestic violence all relevant institutions should act on principle of urgency. Still, even if the principle of urgency is respected, a larger problem lurks in the background. As per report of the Ombudsperson on Gender Equality (Pravobraniteljica za ravnopravnost spolova, 2020, pp. 90-112) courts in Croatia, too, have a mild penal policy, with a high percentage of paroles and fines. When compared to the number of cases per year, only a small number of protective measures is being issued, while the statistics include even cases where protective measure were not implemented until the end. In addition to that, the courts practice confrontation, where victims have to give their statement while looking at the offender. (Zeković et al., 2019, p. 23) This puts additional pressure on victims, who are prone to withdrawing their statements. In NGOs' experience, even $70 \%$ of female victims withdraw their statements, which results in those cases being discontinued (Marić Banje, 2018). Although the number of misdemeanour proceedings is seeing constant decrease, the number of criminally prosecuted domestic violence cases is rapidly increasing. Since 2009 the courts have seen a $70 \%$ increase in the number of criminal cases. (Zeković et al., 2019, p. 23) This only shows that the violence is escalating, and the courts are not implementing the regulations correctly, leaving victims more at risk of repeated violence.

In relation to custody and visitation rights, not much could be found, perhaps due to the lack of reports on these cases or perhaps in matters pertaining to custody and visitation rights the courts and social services are doing a proper job. However, a case in which a woman was forbidden from meeting with her child and found guilty of violence, although she herself was the victim and the child was witness to violence, should not be ignored. The police admitted there were errors in their approach to the case, which was followed by the same in court. Not all facts were taken into consideration, which shows bad practice of relevant institutions. (Pravobraniteljica za ravnopravnost spolova, 2020, pp. 116-117)

\section{CONCLUSION}

Both Serbia and its neighbours have come a long way in adapting their normative frameworks to the international standards on giving protection to victims of domestic and gender based violence. Still, those are simply words on a paper if not properly interpreted and implemented by relevant institutions. From our findings, we can conclude that the countries of the region share similar difficulties in applying rules prescribed by laws. 
A common denominator for false reports is that they often occur during divorce proceedings as a means to get revenge on the spouse or gain advantage in custody battle. Such actions carry criminal responsibility, and on that note, both prosecution and courts should follow up with these charges and have perpetrators properly punished. False reports can cause undue prolongation of court proceedings and could be considered a type of psychological violence, since they create stress for the accused party who is put under suspicion. An increased number of false reports can also cause distrust in courts, which reports witness to. To a degree, the small number of protective measures issued could be blamed on the problem with false reports. In Serbia, this is mostly evident when deciding on eviction. However, false reports can under no circumstances be seen as sole cause of such lenient practices. All relevant institutions should realize that protective measures are necessary, particularly in combinations, in order to provide a measure of protection to the victims and show them that they can trust the law to be on their side. It is a simple equation. In addition to that, relevant institutions should not blindly try to save the institute of "family", but should prioritize, because, especially in cases of domestic violence, human beings cannot be considered a collateral for the better image of society. We believe that much, if not most attention should be put on protective measures, because the entire process of protecting victims from further violence begins with them. Besides the increase in issuance of protective measures, governments should establish a system of monitoring. Issuing protective measures and trusting that perpetrators will obey them bona fide could be a cardinal mistake. Therefore, a monitoring system should be provided.

As for the length of proceedings in cases of domestic violence, the courts in general state that they are taking all actions in a timely manner unless there are unpredicted circumstances. We understand that domestic violence cases imply a multi-institutional approach, but all relevant institutions should be enabled to efficiently inform other institutions involved, all on the principle of urgency and priority for these cases.

Pertaining to the issue of child custody and visitation rights, we once again point out that courts and social services should prioritize and properly implement the standard "in the best interest of the child". Yes, although children have the right to be with both of their parents, and parents have the right to see and be involved in raising their children, when one parent is violent, children are both direct and indirect victims. Their emotional state should be seriously taken into consideration, and their opinion, instead of pushing them further into a stressful situation. In addition to that, children should not be simply separated even from their non-violent parent, especially for economic reasons. Children victimized by domestic violence need a strong support system and to feel safe, while governments and community should help non-violent parents/victims stabilize themselves economically.

Creating a good response system in practice is a long and strenuous process. It requires specially educated and trained professionals, a good monitoring system and, needless to say, funding. It has come to our attention that all of the countries of the region observed in this paper are in need of more staff, which would contribute to more efficiency. However, taking into consideration that the year 2020 has been marked by the COVID-19 pandemic, it is difficult to say how much attention the governments will be willing to show to the problem of domestic violence. Nevertheless, that does not signify that relevant stakeholders should not seek assistance and continue to insist on improvements in practice. 


\section{REFERENCES}

Al Jazeera Balkans, 2020. U Srbiji 11.000 slučajeva porodičnog nasilja, 15 žena ubijeno. $A l$ Jazeera Balkans, $17^{\text {th }}$ Aug. Available from: http://balkans.aljazeera.net/vijesti/u-srbiji11000-slucajeva-porodicnog-nasilja-15-zena-ubijeno (31.08.2020).

Bodiroga-Vukobrat, N. 2018. News Report: Ratification of the Council of Europe Convention on preventing and combating violence against women and domestic violence (Istanbul Convention). European Commission. Available from: https://www.equalitylaw. eu/downloads/4675-croatia-ratification-of-the-council-of-europe-convention-onpreventing-and-combating-violence-against-women-and-domestic-violence-istanbulconvention-214-kb (26.08.2020).

Bogosav, B., 2019. JEZIVA STATISTIKA Za dve godine prijavljeno 110.000 slučajeva nasilja u porodici, ali žrtve i dalje prečesto krive sebe. Blic, $30^{\text {th }}$ Sep. Available from: https://www.blic.rs/vesti/drustvo/jeziva-statistika-za-dve-godine-prijavljeno-110000slucajeva-nasilja-u-porodici-ali/nvdrtcm (31.08.2020).

Broj 223/18. 2018. Zaštitnik ljudskih prava i sloboda Crne Gore. Opinion of $15^{\text {th }}$ June 2018. Available from: https://www.ombudsman.co.me/docs/1528721329_05062018preporuka-csr.pdf (23.08.2020).

CEED. 2012. Studija o nasilju u porodici i nasilju nad ženama u Crnoj Gori. Available from: http://www.un.org.me/Library/Gender-Equality/4\%20Studija\%20o\%20nasilju\%20u\%20 porodici\%20i\%20nasilju\%20nad\%20zenama\%20u\%20Crnoj\%20Gori.pdf (23.08.2020).

CETS, 2011. Council of Europe Convention on Preventing and Combating Violence Against Women and Domestic Violence (CETS No. 210). Available from: https://www.coe. $\mathrm{int} / \mathrm{en} / \mathrm{web} /$ conventions/full-list/-/conventions/rms/090000168008482e (20.08.2020).

Erjavec, D., 2020. U sigurnim kućama brinu: Nasilje bi moglo rasti i nakon pandemije. Radio Slobodna Evropa. 27 $7^{\text {th }}$ May. Available from: https://www.slobodnaevropa.org/a/ nasilje-porodica-bih-izolacija-zakoni/30637779.html (22.08.2020).

Galić N. and Huhtanen H., eds. 2014. Priručnik: Sudska razmatranja slučajeva nasilja u porodici u BiH. Sarajevo: DCAF.

GREVIO. 2018. GREVIO's (Baseline) Evaluation Report on legislative and other measures giving effect to the provisions of the Council of Europe Convention on Preventing and Combating Violence against Women and Domestic Violence (Istanbul Convention) Montenegro. Strasbourg: Council of Europe. Available from: https://rm.coe.int/grevioreport-montenegro/16808e5614 (23.08.2020).

GREVIO. 2020. GREVIO's (Baseline) Evaluation Report on legislative and other measures giving effect to the provisions of the Council of Europe Convention on Preventing and Combating Violence against Women and Domestic Violence (Istanbul Convention) Serbia. Strasbourg: Council of Europe. Available from: https://rm.coe.int/grevio-report-onserbia/16809987e3 (31.08.2020). 
Ignjatović, T. and Macanović, V. 2018. Improved Legislation Failed Protection: Independent report on the implementation of the Council of Europe Convention on preventing and combating violence against women and domestic violence. Belgrade: Autonomous Women's Center.

IPSOS. 2017. Nasilje u porodici i nasilje nad ženama: istraživanje. IPSOS. Available from: http://www.un.org.me/Library/Gender-Equality/Istrazivanje\%20UNDP\%20o\%20 nasilju\%20u\%20porodici\%20i\%20nasilju\%20nad\%20zenama\%202017.pdf (23.08.2020).

J.B.Č., 2019. Osim udaljavanja iz stana zabraniti i približavanje i uhođenje. Radio i Televizija Crne Gore, $27^{\text {th }}$ Dec. Available from: http://www.rtcg.me/vijesti/drustvo/263763/osimudaljavanja-iz-stana-zabraniti-i-priblizavanje-i-uhodjenje.html (23.08.2020).

Marić Banje, K., 2018. Nasilnici izmiču zakonu jer čak 70 posto žena povlači prijave, a jedna stvar bi tome mogla stati na kraj. Slobodna Dalmacija, 22nd Jan. Available from: https://slobodnadalmacija.hr/vijesti/hrvatska/nasilnici-izmicu-zakonu-jer-cak-70-postozena-povlaci-prijave-a-jedna-stvar-bi-tome-mogla-stati-na-kraj-527505 (26.08.2020).

Ministarstvo pravde. 2016. Izvještaj o sprovođenju Zakona o zaštiti od nasilja u porodici za period 2010-2015. Podgorica: Ministarstvo pravde Crne Gore.

Muftić L.R. and Cruze J.R. 2014. The Laws Have Changed, But What About the Police? Policing Domestic Violence in Bosnia and Herzegovina. Violence Against Women, 20(6), pp. 695-715. DOI: 10.1177/1077801214540539.

Mušić, S. 2018. Nasilje u porodici kroz pravni okvir u Bosni i Hercegovini. Zbornik radova Pravnog fakulteta Sveučilišta u Mostaru, XXVI, pp. 168-187.

OSCE. 2019. OSCE-led survey on violence against women: Bosnia and Herzegovina. Vienna: OSCE Secretariat. Available from: https://www.osce.org/files/f/documents/3/5/423470_1. pdf (20.08.2020).

Petrić, A. et al. 2019. Response to Violence Against Women - Unprotected Survivors: Alternative Report of Nongovernmental Organizations from the Bosnia and Herzegovina to GREVIO Group. Banja Luka: Foundation United Women Banja Luka. Available from: http:// unitedwomenbl.org/wp-content/uploads/2020/04/Alternative-Report-of-NGO-fromthe-BiH-to-GREVIO-Group.pdf (20.08.2020).

Petrušić, N. et al. 2018. Krivično delo nasilja u porodici u sudskoj praksi: nove tendencije $i$ izazovi. Beograd: Misija OEBS-a u Srbiji.

Pravobraniteljica za ravnopravnost spolova. 2020. Izvješće o radu za 2019. Zagreb: Pravobraniteljica za ravnopravnost spolova. Available from: https://prs.hr/attachments/ article/2894/IZVJESCE_O_RADU_ZA_2019_Pravobraniteljice_za_ravnopravnost_ spolova.pdf (26.08.2020).

Prvo Osnovno Javno Tužilaštvo u Beogradu. 2018. Lažno prijavljivanje i lažno svedočenje kod nasilja u porodici. Prvo Osnovno Javno Tužilaštvo u Beogradu, 12th Sep. Available from: https://prvo.os.jt.rs/saopstenja/lazno-prijavljivanje-i-lazno-svedocenje-kodnasilja-u-porodici/ (29.08.2020). 
Raić Knežević, A., 2020. Mučna priča čovjeka koji na sudu dokazao da ga je bivša supruga maltretirala i lažno prijavljivala za zlostavljanje. Telegram, $4^{\text {th }}$ Jan. Available from: https:// www.telegram.hr/politika-kriminal/mucna-prica-covjeka-koji-na-sudu-dokazao-daga-je-bivsa-supruga-maltretirala-lazno-prijavljivala-za-zlostavljanje-i-branila-mu-davidi-sina/ (26.08.2020).

The Advocates for Human Rights \& the Autonomous Women's Center. 2017. Implementation of Serbia's Domestic Violence Legislation: A Human Rights Report. The Advocates for Human Rights. Available from: https://www.theadvocatesforhumanrights.org/uploads/ serbia_report_final.pdf (29.08.2020).

Tulumović, M. 2018. Krivično djelo nasilja u porodici u praksi općinskih sudova tuzlanskog kantona. Zbornik radova Pravnog fakulteta u Tuzli, IV(1), pp. 44-75.

Udruženje žena sudija u Bosni i Hercegovini. 2012. Analiza stvarnog stanja u smislu izricanjaili neizricanja zaštitnih mjera iz Zakona o zaštiti od nasilja u porodiciFederacije Bosne i Hercegovine. Sarajevo: Fondacija lokalne demokratije. Available from: https:// www.fld.ba/upload/documents/Analiza_nasilje_USAID_JSDP_II_U\%C5\%BDSBIH. pdf (20.08.2020).

Zeković, B. et al. 2019. Zaštitne mjere i mjere bezbednosti u kod kaznenih djela nasilja u porodici: Analiza medunarodnog i nacionalnog pravnog okvira i prakse Podgorica: SOS telefon za žene i djecu žrtve nasilja Podgorica.

Zeković, B. et al., eds. 2017. Domestic Violence in Montenegro: Theory and Practice (monitoring study). Pogorica: SOS telephone for women and children victims of violence Podgorica. 